\title{
The Boxers of Kabul: Women, Boxing and Islam
}

\author{
Hillary Kipnis and Dr Jayne Caudwell \\ University of Brighton
}

\section{Introduction}

In this chapter we focus on women who box, in particular Muslim women who box. Within Sport Studies and the Sociology of Sport there is limited discussion of this topic; Mitra (2009) offers one of few accounts. In the literature, there exist broader discussions surrounding women, Islam and sport and/or physical activity (cf. Benn et al., 2010; Hargreaves, 2001; Kay, 2006; Walseth and Fasting, 2003), as well as analyses related to the histories of women boxers (Hargreaves, 1997; van Ingen, 2013), women's boxing bodies (Halbert, 1997; Mennesson, 2000), boxing uniforms (van Ingen and Kovacs, 2012), boxing and the Olympics (Lindner, 2012), and women boxers in film (Boyle et al., 2006; Caudwell, 2008; Fojas, 2009). Many of these contributions take a feminist perspective to the sport of boxing.

The 2012 London Olympics provides a watershed moment, globally, for women's entitlement to box. Until very recently, numerous national and international governing bodies of boxing ruled against providing the opportunity for women and girls to box. In 1988, the Swedish Amateur Boxing Association was one of the first to withdraw bans and sanctions against women and girls. The UK was slow to follow and the case of Jane Couch MBE, a decade later, illustrates the depth of sexism involved. On 15th August, 1998, Couch successfully reversedvia an industrial tribunal-the British Boxing Board of Control ruling that refused her a boxing license on the grounds that premenstrual syndrome made women 'unsuitable'. Again almost a decade later, on 14th August, 2009, the International Olympic Committee (IOC) officially recognised women's boxing (men's boxing has been an Olympic sport since 1904), and on August 9th, 2012, British boxer Nicola Adams and Irish boxer Katie Taylor won gold medals at the Olympics. Yet despite these shifts in the governance and regulation of women's boxingand significant to this chapter-on July 18th, 2012 the International Boxing Association denied Sadaf Rahimi the opportunity to box at London 2012.

Sadaf Rahimi, an Afghan boxer, along with Fahima Mohammad and Shabnam Rahimi, appeared in the UK press during the months leading up to London 2012. All three trained and boxed in Kabul and they became newsworthy because they seemed to go against the popular stereotypes of not only gender, but also Western notions of Islam and Muslim traditions. Before we consider these mediated stories from a perspective of Orientalism (Said, 1978; 
1981), we discuss the contexts faced by Afghan women boxers living within a Muslim-majority, war-torn country. Towards the end of the chapter, we unpick how Western media has configured these women boxers within Western mediated news stories influenced by the waron-terror (WOT).

We offer a backdrop, albeit truncated, to help develop an understanding of Islam, Afghan society and sport. We acknowledge that this account is through the lens of our subjectivities as white Western feminists from the USA (Hillary) and the UK (Jayne). Although we do not discuss this position in this chapter, we do recognize that we are providing insights that are from the privileged position of whiteness. Following our introduction to Afghanistan society, we then turn to the women boxers of Kabul and consider the many obstacles they must overcome to box. Finally, we discuss how Western media have represented Afghan women boxers. We explore the complexities and imbrications of Orientalism, Islamophobia and Western (UK \& USA) promulgated discourses of the so-called war-on-terror. Within the sociology of sport, we have some understanding of men's sport and mediated representations of Islam and boxing (Burdsey 2007), and Islam and cricket (Malcolm, Bairner and Curry, 2010); however, there is limited analysis of the Afghan women boxers. This chapter offers a preliminary contribution.

\section{Islam, Afghan Society and Sport}

Islam, as it is reported in the Western media, has been oversimplified and presented as a monolithic threat to the West, especially in the aftermath of 9/11 (Joseph, 2014). By association, Muslims, or followers of the religion of Islam, have been portrayed by certain sections of the media as 'terrorists', barbaric and violent (Burdsey, 2007; Saeed, 2007). Muslim women are often singled out in the media's negative reporting, specifically women who wear the hijab, or head covering (Khalid, 2011; Zempi, and Chakraborti, 2014). Indeed, the trend in the media is to characterize Muslim women as weak and docile or linked to Islamic fundamentalism (see Bing, 2010; Women's Hour, 14 July, 2014). Rarely are the women the media reports on given the opportunity to contribute their views (Khalid, 2011). Thus the Western media's portrayal of the Muslim world can be faulted for selecting negative news and maintaining bias (Said, 1978). This is disconcerting considering the fact that the media is the medium through which non-Muslims in the West are often introduced to Islam.

Sfeir (1985), and Harkness and Islam (2011), provide an account of Islam and Muslims, which the media overlooks, when they explain that Islam is more than a religion, that it has a unique history, art, philosophy and legal system. Harkness and Islam (2011) explain that Muslims from Turkey, Palestine, Indonesia and Afghanistan share the core beliefs Islam has to offer, but they will differ in terms of the branch of Islam they follow as well as in their cultural and traditional 
practices. Equally important to understanding the role of Islam for individuals and the societies they reside in is the influence of the legal and political framework that governs them.

Afghanistan is a conservative Islamic state, which means that the state Constitution recognizes that no law can override Shari'a law (Islamic law). It is also a Muslim-majority country comprised of various ethnic groups and tribal affiliations. The disparate culture and traditional practices of the various ethnicities living in Afghanistan and its legal system are together what makes Afghan Islam unique to Afghanistan. Significantly, for Afghans, 'Islam is a complete set of beliefs, where every matter in a Muslim's life is governed by divine guidelines provided through the Qur'an and Sunna' (Radzi, 2006, p.34-5). Importantly, Islam influences gender relations in Afghan society.

Three important overlapping features of Afghan society, which are highly relevant to understanding gender relations are: Izzat (honour-shame), the public/private distinction, and the notion of the community. Although each can be explained individually, their full meaning and effect can only be understood together. We introduce them briefly, but we return to them throughout the discussions that follow.

Izzat, or honour-shame, is an important feature of Islam and Afghan society. Women are responsible for maintaining familial honour, doing so through their behaviour and by regulating their sexuality. One example of this is Islam's requirement of modest dress. Clothing is a complicated issue and in recent debates with women who follow Islamic religion and culture, it is argued that some women prefer these dress codes and chose to wear items such as the hijab and burqa (see Abu-Lughod, 2002; Women's Hour, 14 July, 2014; Zempi and Chakraborti, 2014).

Passages in the holy book of Islam, the Qur'an, have been interpreted as promoting a separation of gender roles in accordance with the public and private domain. Muslim women from a conservative Islamic background are strictly regulated in the public sphere to ensure they are not putting their, and their families, honour at risk. For this reason, they must make a concerted effort to observe socio-cultural norms of behaviour like not socializing with non-male relatives. (Nakamura, 2002). Within the private domain, the majority of women have more freedom. As with many non-Muslim women, they tend to be in charge of household duties and care for children. Men, on the other hand, are required to protect and provide for their families (Rostami-Povey, 2007).

Another equally important feature of Afghan society that impacts women is the notion of community. Whereas in Western societies-and arguably since the Regan-Thatcher eraindividualism and exercising individual autonomy is an important cultural (and economic) 
feature, in Afghanistan the opposite is true. Afghanistan places greater emphasis on family units and the community (Rostami-Povey, 2007). For women, their family unit and their community observe, govern and pass judgment on their behaviour in the public domain.

As reported elsewhere (Benn et al., 2010; Hargreaves, 2001; Kay, 2006; Walseth and Fasting, 2003), the religion of Islam encourages men and women to participate in sport. Indeed, the Qur'an has many Surahs (chapters) instructing Muslims to maintain their physical and mental strength. Moreover, a popular and often re-told Hadith (oral anecdotes on the life and sayings of the Prophet Mohammad) relates to a race between the Prophet Mohammed and his wife, Aisha.

Further evidence to support Islam's approval of female athleticism is the rise since the latter part of the 20th Century in the number of Muslim female athletes throughout the world, as well as newly established sporting organizations and Islamic women's sporting competitions. Although the contingency of Muslim sportswomen is relatively small, they have gained recognition locally and worldwide for their athletic achievements, such as: Fatima Al-Nabhani (Oman, tennis player), Roqaya Al-Ghasara (Bahrain, sprinter) and Marzuna Chorieva (Tajikistan, boxer). As a consequence, many nation-states provide for the needs of Muslim women wishing to engage in sports. They do this by allocating financial support, providing training facilities and by organizing local, regional and international competitions. In Central Asia, Iran has been a significant leader for women in sport and this is reflected by an increased number of women athletes who competed at London 2012. In 2004 (Athens), there was one female athlete in the Iranian Olympic team and 37 men. In 2008 (Beijing), three female and 52 male Iranian athletes attended the Olympics. At London 2012, there were eight women and 45 men in the Iranian team. In addition to these increased Olympic opportunities for Iranian women, Iran hosted the first Women's Islamic Games in 1993 as well as three subsequent games (1997, 2001 \& 2005).

While sport is undeniably important in Islam and permissible for women, the question becomes, why are there still so few Muslim sportswomen? Some time ago, Sfeir (1985) explained that it is conservative cultural beliefs and practices that present obstacles to women, which may deter them from sport. More recently, Nakamura (2002), Radzi (2006) and Harkness and Islam (2011) have explored the following three obstacles confronted by Muslim women athletes: (1) dress (2) sex segregation and (3) controlled access to physical activity space. Again, these are dependent on a woman's individual circumstances, laws and rights in their country, the type of sport they practice, and where they compete.

With respect to dress, this can act as an obstacle in two ways. Firstly it can be a hindrance for performing some forms of elite, competitive sport. Secondly, in relation to international events, 
women may be prevented from participating due to rules that ban the hijab or enforce a specific dress code. For example, it is only recently that the world governing body for association football, FIFA, along with the IOC, reversed the ban on athletes wearing the hijab. Elsewhere, athletes who wished to compete in beach volleyball, for instance, may have found it impossible because until very recently, the IOC-affiliated governing body, the Fédération Internationale de Volleyball, required women to wear short, tight shorts and this is not possible for many women who follow Islam because such disregard for modesty goes against cultural sensibilities.

Sex-segregation is a second obstacle scholars have identified as preclusion for Muslim women engaging in sport. Kay (2006) makes the point that this is not a universal issue, but that conservative Muslim women may not feel comfortable and/or their families may not permit them to train and compete if members of the opposite sex are present, which includes male coaches. Providing female-only training spaces can pose a problem, which is particularly pronounced in states that are war-torn or impoverished, such as Afghanistan, as they may not have the resources to provide women-only training facilities and have female coaches.

A third obstacle, which is also in relation to sexuality, is that women in Islam are believed to cause chaos, or fitnah (this is a complicated concept, which can be interpreted as 'temptation'), due to beliefs surrounding seduction, who can be seductive, and who can be seduced (Walseth and Fasting, 2003, p.54). In a very simplistic understanding, women's bodies are viewed as seductive and male members of society are viewed as open to seduction. Walseth and Fasting (2003) report that fitnah is an important consideration for conservative Muslim women engaging in sport. Their research determined that Muslim women will refrain from engaging in physical activities in front of men that may be considered sexually provocative and dishonourable - like aerobics, which involves jumping and raising legs. That is not to say that aerobics is a forbidden activity, just that certain women will refrain from aerobics in front of men unless they have access to 'women-only' physical activity space (Walseth and Fasting, 2003). With these points in mind, our discussion now turns to the experiences of women boxers in Afghanistan.

\section{The Boxers of Kabul}

Some of the inspiration to form a women's boxing team in Afghanistan has been accredited to the male Afghan former boxer, Sabir Sharifi (see The Girl Boxers of Kabul, 2012). In February 2007, the ex-boxer sought to recruit interested girls and young women from local schools. This was once their families had given their consent and approval. Receiving parental approval is one of the many obstacles these boxers have to overcome in order to box. With no financial support, no training facilities and minimal equipment the girls and young women were initially 
trained in their own homes. However, soon after, a local Afghan organization called the Cooperation for Peace and Unity (CPAU) joined by the charity Oxfam lent technical and financial support. This made it possible for 25 girls and young women aged between 12-25 years to box. CPAU created the Fight for Peace program; a program designed to provide the boxers with educational courses in conflict, and conflict resolution skills, in addition to boxing training. CPAU aimed to develop the potential of these girls and young women for breaking ingrained gender stereotypes. Moreover, they envisaged the possibilities for the boxers to become global ambassadors for Afghanistan, believing that this might help transform the negative worldview of Afghanistani.

Another big development, also in 2007, was the establishment of the Afghan Amateur Women's Boxing Association (AAWBA). In 2009 the women's team boxed competitively, often winning regional and international competitions. For example, at the Asian Indoor Games in Vietnam in 2009, Shahla Sekandari won a Bronze medal. The following year, Sadaf Rahimi and Shahla Sekandari fought at the Asian Women's Boxing Championship in Kazakhstan. In 2011, Shukria Haidary and Sadaf Rahimi made it to the Amateur International Boxing Association (AIBA) Women's and Youth Junior World Boxing Championships in Turkey. Again in 2011, Shabnam Rahimi won gold, Sadaf Rahimi won silver and Fahima Sherzad won bronze at Championships in Dushanbe, Tajikistan.

Then, In 2012, Sadaf Rahimi and two of her teammates competed in the AIBA 7th Women's World Championships in China. This was an important competition because it would determine who would go on to fight at the London 2012 Olympics. Unfortunately, Sadaf Rahimi's fight against Poland's Sandra Drabik was stopped 1 minute 26 seconds into the first round. Losing this fight meant that Sadaf Rahimi's only chance to reach the 2012 Olympics rested with the IOC Wild Card decision.

Rahimi's hopes of Wild Card entry to the Olympics were dashed when the IOC made a contentious decision and refused on safety grounds. The IOC concluded that Rahimi lacked the boxing experience and skills necessary to compete against competitors from nations where boxing was more developed. Long before the AIBA World Championships in China, the Western media was incorrectly claiming that Rahimi would be at the Olympics. News outlet Al Jazeera (2012) admitted it was surprised by the IOC's decision, as they thought the media attention on Rahimi would sway the IOC decision in awarding her the Wild Card spot.

The achievements of the Afghan female boxing team, within such a short period of time (from 2007 to 2012), and during a period of civil unrest, conflict and war, reflect the determination of these women boxers. Their participation in boxing can be seen in light of seemingly 
insurmountable obstacles. In addition to the three obstacles briefly outlined above, below we offer further discussion on the conditions these women faced.

In many ways, the young women who joined the Afghan female boxing team constitute an exception to the exception. Put differently, most girls and women in Kabul, and throughout Afghanistan, do not have the opportunity to participate in a sport such as boxing due to prohibiting features inherent in Afghan society: widespread poverty, early marriages, endemic societal violence and insecurity. In addition, as we have highlighted earlier, the daily lives of girls and women are regulated by customs, social attitudes and male control of the public domain.

As well as being an Islamic state, Afghanistan is a socially conservative patriarchal society. Under Islam, and by extension Afghan families, communities and society, women are expected to maintain honor and respect (izzat). Women perceived to be engaging in nonconventional activities are judged by their family as well as by their neighbours (Baker, 2012). If a woman evokes shame her entire family shares this shame. Because boxing is viewed as an 'unconventional' sport that often involves travel and the potential for the young women to be in the company of the opposite sex, the boxers must overcome accusations that they are bringing shame to their families. At the same time as negotiating boxing participation and izzat, the boxers negotiate surveillance by their wider communities. Boxer Safoora describes what happens when she is recognized as a boxer while she is out in public:

They are not only watching you. You can see the hate in their face, in their eyes. Why? Because you are a girl and you came out. Outside they have a small mind and can oversee their own family and nothing else. "My daughter is the best, she is wearing a burqa, she is staying at home". "But look at her". "She is one of the bad girls". (in Wijnen, 2012, p.77)

Often, one of the first obstacles girls and women who want to box must overcome is parental approval. The boxers are fortunate in that their families have allowed them to participate. In Sadaf Rahimi's case, it was her mother who supported her daughter's decision to box. The following quote from Rahimi illustrates that many girls and young women aspire to box, but their daily life experience are strictly controlled:

I am a lucky Afghan girl who has permission from her family to go out and play sports. Other girls are more restricted. A neighbour's girl lives around the corner. She cannot go to school, or play sports. She cannot even leave the house. They see me sometimes and say: "Sadaf you are so lucky. You are able to play sports and go to school, and travel 
abroad". They say: "We long for the day when we can go abroad too". (from the documentary The Boxing Girls of Kabul, 2012)

Not unlike societal views on women's boxing in the UK and USA, there are many Afghan men and women who think that women should not box (Baker, 2012). On top of family and community approval, young women face the expectations associated with the institution of marriage. As with religious and cultural traditions elsewhere, Afghan women usually marry when they are young. Most young women who are engaged or married are forced to quit boxing by their husbands. This happened to the Olympic hopeful Shahla Sekandari when she married and moved away from Kabul (Baker, 2012). Hosai, a boxer from the Afghan Women's Boxing Team, speaks of how Afghan men still treat their wives like property and are the reason why many are forced to end their boxing careers:

...I do not have a good idea about marriage. When someone gets married her life completely changes. When I look at my sister before and after engagement I see two different people. Before that she did everything she wanted. Now her husband tells her what to wear and what to do. She should ask permission for everything. Because of this I do not want to marry. In our society it is like that. When girls get married they cannot do things like boxing anymore. (in Wijnen, 2012: 73)

Boxing can be a dangerous sport because there is potential for physical harm and damage to the body. These dangers are layered on to the consequences of causing shame to self, family and community as well as the dangers they faced living in a country at war (Crane, 2009). However, for some female Afghan boxers the risks are relative. They appear less concerned given the hazards they face in Afghan society, which can include travel and individual security (see The Boxing Girls of Kabul, 2012). One way the security situation in Kabul presents an obstacle is that it makes it difficult, if not impossible, for the girls and women to travel to attend training. Their boxing club is located at the Ghazi Stadium, which is outside of Kabul. They must travel on the only road that leads to the main airport in Kabul, a road notorious for sporadic outbreaks of violence and bombings.

When CPAU and Oxfam supported the boxing team, a driver and secured vehicle would transport the boxers from their homes to the club. Since the steady withdrawal of financial support from CPAU and Oxfam the young women have lost their transport and make their own way to the boxing club. Due to their boxing success and media attention, the boxers are often recognized and as a consequence they receive harassment in public spaces. There are many individuals who consider their boxing as 'un-Islamic'. Many of the young women have learned to cope with harassment, some conceal their boxing identities and some ignore comments 
choosing to focus less on the harassers and more on what they gain from boxing (cf. Wijnen, 2012; The Boxing Girls of Kabul, 2012).

Team members, and their families, have endured death threats. Both Olympic hopeful boxers Sadaf Rahimi and Shahla Sekandari received such threats after they captured the media spotlight for victories at international boxing competitions (Wash and Mobasherat, 2012). Sadaf Rahami's father also received threatening telephone calls and he banned Sadaf from boxing for a couple of months. As a consequence of the coach's intervention and assurances, Sadaf Rahimi returned to box and pursue her opportunity to compete for an Olympic place (Flack and Sadat, 2012).

\section{The War-On-Terror, Media and the Boxers of Kabul}

In his seminal book, Orientalism (1978), and throughout his academic career, Said has exposed how Western politicians and the media maintain an 'us-versus-them' approach to reporting on Islam. He purports that the West portrays its society as more rational, civilized and progressive and mischaracterizes the Orient/Non-Western world as irrational, violent and backward. Orientalism, according to Said, has served a purpose; to justify Western interference in the Non-Western world. The WOT, including the Western-led invasion of Afghanistan, has arguably revived Orientalism, as evidenced in the work of Abu-Lughod (2002) and Khalid (2011), who adopt a gendered orientalism in their research on the media portrayal of Muslim women.

By failing to put stories into a broader context, the media is often criticized for presenting stories that replicate 'stereotypes and existing political and social agendas' (Fahmy, 2004: 93). In the case of the Afghan boxers, it is more complicated than this. The media can be praised for reporting stories featuring Muslim women that do not always connect with WOT. In the case of the Kabul boxers, by reporting on Muslim boxers with talent, power and a voice, the media defied some gendered and ethnic stereotypes. However, there is evidence to suggest that the Western media coverage was heavily influenced by the Western political agenda in relation to the war in Afghanistan (Joseph, 2014). To place the media coverage of the Kabul boxers in a broader context, we offer an abridged version of the Taliban rule and US-led NATO intervention. This helps form a clearer understanding of women's rights in Afghanistan.

Present-day Afghanistan has endured over three decades of war which have shaped and influenced modern Afghan society and culture in multiple ways - too many to fully discuss here. Suffice to say, war and conflict have affected Afghan society by straining relationships amongst Afghanistan's multiple ethnic and tribal communities, devastating the Afghan economy, creating a large-scale refugee problem, and destroying its state institutions and transportation 
infrastructure. Consequentially, long-term, on-going war and conflict has left Afghanistan in a weak and fragmented condition (Baker, 2012).

Brief but damaging, the Taliban rule in Afghanistan was from 1996 until their fall in December 2001. The Taliban aspired to return Afghanistan to a fundamental form of Islam and enforced their rule with unbridled force and brutality. While both men and women suffered under the Taliban, women were relegated in their status as citizens. In many ways, they became noncitizens, losing many of their human rights (Amnesty International, 2013). The Taliban made it illegal for women to work, obtain an education and to be out on the street without being escorted by their husband or male relative". Additionally, the Taliban further eroded women's autonomy when it came to public dress by making it illegal to be out in public without a burqa. The Taliban also banned all sport and turned the football stadium, Ghazi Stadium, into a site for public executions. Many women were hung, shot and stoned to death in the Ghazi Stadium. Today, the Ghazi Stadium is the location for the women and girls' boxing club (Wash and Mobasherat, 2012).

For five years, the Taliban's brutal regime went un-admonished by the international community. Then, 9/11 occurred and Osama Bin Laden became the USA's most wanted foreign criminal for his lead role in the bombings. With the possibility that Bin Laden was hiding in Afghanistan, under the protection of the Taliban, the USA pled a case to the UN Security Council to allow NATO forces to invade Afghanistan. Support for the invasion was buttressed by the media, which provided widespread coverage of the Taliban's brutality towards humanity, and in particular, towards women. It can be argued that the American-led war in Afghanistan was propagandized in the USA and UK, and the propaganda included the liberation of Afghan women (Fahmey, 2004; Rostami-Povey, 2007). Although the stated intentions of the NATO intervention and then occupation of Afghanistan appeared justified, it is apparent that the invasion was not, among other things, for the sake of women. Indeed, some claim that more harm has been done than good in terms of elevating women's rights in Afghanistan (Stabile and Kumar, 2005; Rostami-Povey, 2007).

Khalid (2011) argues that the 'women's rights rhetoric is a central part of the WOT discourses as articulated by media, officials and US-based feminists' and that this discourse was often used by the USA to 'justify military violence' (p. 19). As Abu-Lughod (2002) points out, the Revolutionary Association of Afghan Women (RAWA), which had been campaigning for women's rights since 1977 in Afghanistan and pleading for international attention when the Taliban gained power, expressed their opposition to American bombing of Afghanistan. RAWA considered the bombing campaign as contrary to 'Afghan women's salvation' and only serving to exacerbate their hardship and loss (Abu-Lughod, 2002: 789). 
Indeed, Rostami-Povey (2007) and Graham-Harrison (2014) have argued that Afghan women in the 2010s have fewer rights in society than prior to the Taleban rule. Rostami-Povey (2007) notes that girls noticeably lag behind in education, more families are impoverished, and that there has been a rise in the number of 'women forced in to the sex industry, cases of selfimmolation, rise in suicides, increased numbers of inter-family violence (honour killings)' (p. 12). There is also evidence that families are dressing their girls as boys in order for them to receive an education and continue to work in family businesses (Qadiry, 2012). Moreover, people who openly advocate for the rights of women or work in women's rights organizations are frequently threatened and some have been murdered (Rostami-Povey, 2007; Amnesty International, 2013). Meanwhile, turning to government officials is often not an option as there is evidence to suggest that authorities frequently ignore women's complaints (Rostami-Povey, 2007).

Recent Western media coverage of the Kabul boxers has frequently made reference to the poor status of women's rights in Afghanistan, but apportioned blame mostly on Afghans and their conservative culture. President Hamid Karzai's attempts to reverse newly established laws to protect victims of domestic violence, the deteriorating security situation accompanied by the rise in violence, as well as the continuation of endemic problems of poverty and lack of education have often been the focus of Western media (Sanar, 2012). While the Afghan authorities are partially responsible for the breakdown of women's rights, the media avoided the impact the Western occupation of Afghanistan had on women's rights. Rostami-Povey (2007) maintains that the Western occupation of Afghanistan harmed the development of women's rights and made Afghanistan more insecure for women through its disregard of Islam, daily acts of harassment and violence, and lack of socio-political development in relation to gender.

In particular, Afghans, according to Falk (2012), recall how Western forces burnt the Qur'an and how they have personally experienced or heard personal accounts of the harassment of family members at the hands of Western forces. In addition, US President Obama's use and escalation of drone weaponry killed significant amounts of innocent civilians, including women and children (Ackerman, 2012). In view of these incidents, it is easy to see how any idea or policy that is associated with the West conjures up negative memories and emotions and might be disregarded. Moreover, in carrying out these acts and not securing women's rights, the West is viewed as having waged a war against Islam. As a consequence, the West has lost support amongst many Afghans (Steele, 2012).

\section{Western Mediated Representations}


For the purposes of this chapter, 'Western media' refers to major print media in the UK and the USA. This focus is because, according to Joseph (2014), the USA and UK dominate the international news system, and because the media is often the first, and only introduction to Islam and Afghanistan that non-Muslims in the West receive. As Said (1978) highlights, media representations serve to portray what he calls the Orient as 'other'. One way this is achieved is through positioning Islam as a monolithic religion underpinned by religious barbarism.

Our findings reflect a preliminary study and as such we searched google, LexisNexis and UK Newsstand to find articles that covered the Afghan boxing team from its foundation in 2007 through to 2014. Overall, there were few results, which is telling. We focused our analysis on the larger, mainstream media reports because they reach a wider audience and have a broader reach in shaping public opinions. Collectively, the articles selected were critically assessed under the lens of gendered orientalism and the WOT discourse (Khalid, 2011). Put bluntly, the Western media coverage of the Afghan boxers reinforces the WOT and political agenda of the West in the following ways: in the decision to cover certain stories and exclude others; and through the characterization of the boxers and women in Islam.

Joseph (2014) argues that the Western media covers 'Third World' news stories when they have a vested war interest. The current WOT and the US and UK troops and financial investment in Afghanistan helps explain why the Afghan boxers received attention in the Western media. One indicator of the Western media bias towards war-torn Afghanistan is the lack of coverage female boxer, Mavzuna Chorieva of Tajikistan received throughout the 2012 Olympics. This invisibility is striking if we compare Chorieva's achievements with those of Afghan boxer Rahimi, who was given mainstream media attention.

Tajikistan and Afghanistan share similarities related to geographic location, civil war and conflict, and cultural and religious traditions. Geographically, Tajikistan and Afghanistan are located in Central Asia and they share borders, similar customs and beliefs. Tajikistan, like Afghanistan, suffered from a civil war (1992-1997) that devastated the country, and its economy has not fully recovered, making it one of the poorest countries in the region ${ }^{i i i}$. Also similar to Afghanistan, women's rights in Tajikistan have been hemmed in by conservative cultural beliefs. Thus, it can be said that both Chorieva and Rahimi are boxers from conservative, Islamic, war-torn countries where the opportunities for women in sport are limited and where being a sportswoman is not widely accepted on account that it defies social customs according to conservative Islamists.

Arguably both boxers having overcome several serious obstacles to participate deserve equal media attention, especially under the rhetoric of women's liberation. However, as Western 
media focused on Rahimi, mistakenly portraying her as having secured a spot at the 2012 Olympics, Chorieva received no coverage. Even after Chorieva won a Bronze medal at the 2012 Olympics, which made her the first-ever Muslim woman to win an Olympic medal in boxing, the Western mainstream media did not report, in detail, her story of success.

Indeed, Chorieva's boxing successes reflect a remarkable journey. Very briefly, she learned to box disguised as a boy so that she could spar and compete (Sodiqov, 2012) and she was the only Tajik Olympic team member out of 16 to win a medal at the 2012 Olympics (Hokim, 2012). And yet, her presence at the Olympics went largely un-reported. Instead, there were numerous news stories of the Afghan boxers. We suggest the mediated invisibility of Chorieva is because Tajikistan was not part of the WOT.

Moving on from this initial point, we consider the ways the Afghan boxers were represented in the selected media. Byng (2010) argues that Muslim women typically are featured in Western media in connection with stories involving their victimhood status, patriarchy, the veil, fundamentalist Islam and terrorism. Powerful Muslim women are hardly featured and when they are it is rare for the media to solicit their views and opinion (Byng, 2010). Since 9/11, Khalid (2011, p.15) maintains that 'gendered and orientalist depictions of the Middle Eastern or Islam 'Other' have been highly visible in the Western world in both official discourses and mainstream media'.

In the case of the Afghan boxers the media can be credited for breaking from the norm and featuring physically strong Muslim women and including their comments. However, we argue that the WOT continues to serve as the dominant frame dictating this media coverage. AbuLughod (2002) and Khalid (2011) contend the West often framed their WOT media discourse in terms of 'othering' Muslim women. Women's rights and veiling continues to be used, by the West, to highlight women's inequalities and repression in non-Western societies. And yet, as Abu-Lughod (2002) points out it is misguided to reduce a women's freedom to a piece of clothing. She contends that this Western-centric view fails to recognize the many other representations the veil has for women in society, such as serving as a sign of their faith (AbuLughod, 2002).

We did not find a dominant fixation on the veil in representations of the women boxers. However, we did find cases of how Muslim women's clothing was used to 'other' and to metaphorically convey messages of freedom and liberation. Examples include, The Sunday Telegraph (25 July 2010), which highlighted that 'traditional hijab clothing beneath tracksuits ... look[s] incongruous as they trade punches and skip around the dilapidated room in a heartwarming bid to make the London 2012 Olympics', and went on to position women's rights in 
terms of the burqa: 'outside, women hidden by billowing burqas must struggle for any semblance of independence in a deeply conservative society.'

We did find that the dominant discourse, conveyed through catchy headlines and including several boxing metaphors, was of liberation, freedom and equality. Some exemplars include: 'The freedom fighters of Kabul' (The Sunday Telegraph, 25 July, 2010); 'Fighting out of Kabul: The sisters determined to fight a blow for freedom at the Olympics' (The Times, 26 May, 2011); 'Afghan females aim to box clever for women's rights' (The Telegraph, 5 March, 2012); 'I'll proudly fight for women and Afghanistan' (The Guardian, 12 March 2012); 'Afghan girls punch their way to equality' (NBC News, 20 December, 2011) and 'Afghan women strike blow for equality' (BBC News, 17 November, 2011).

These freedom and liberation narratives align women's rights with Western cultural standards and notions of American and British Women's Liberation Movements. A specific example, provided by Baker (2012) in her article on the boxers, claims that Afghan women 'are still a long way away from enjoying the independent lives most women take for granted in the West'. Such a framing clearly reflects Khalid's notion of Gender Orientalism because the standard set is that of the West. Women's liberation is complicated and Balboul (2000, p.165) explains that some Muslim women fear that becoming Western means that they will be subjected to a way of life that promotes 'moral laxity, pornography, casual sex, materialism and the disappearance of the family'.

Clearly, through metaphors of fighting, the stories align the Kabul boxers with war and in this way the boxers become extensions of the war effort in Afghanistan. The language reflects the interests of the West in Afghanistan, namely the liberation-of-women myth. One of the stated purposes (see Laura Bush Radio Address) of the West's war in Afghanistan was to overthrow the Taliban so that women in Afghanistan would be liberated (Abu-Lughod, 2002).

The NATO occupation of Afghanistan has exacerbated women's insecurity and made women's rights agendas throughout Afghanistan unpopular (Rostami-Povey, 2007). In addition, the West's military withdrawal resulted in loss of humanitarian aid and media attention. As the main provider of security for Western agencies, there is a likelihood that when NATO and American troops leave, these agencies will follow due to their concerns that they will be left vulnerable to attacks by the Taliban. For the Afghan boxers these concerns are valid; they have lost the financial support of CPAU and Oxfam. Previously-when the team had 29 boxers-each member received 50-80 pence per day and travelled by secured transportation to and from training. In 2014, the team is down to 12 , no-one receives a stipend and they must find their own transport to and from boxing training (Hossaini, 2014). The Afghan Olympic Committee has 
taken over supporting the team; however, in a poor country like Afghanistan, they are not well endowed with funds. Significantly, these post-Olympics circumstances do not appear in Western media. Their absence suggest that the media's aim to represent women's equality and liberation was ephemeral; it lasted for the period leading up to the Olympics, but with no longstanding commitment to document Afghan women and girls' rights in society and in sport.

Post-London 2012, the Afghan boxers were invited by the Foundation for Women in Sport and the Fawcett Society to commemorate International Women's Day 2013. The main event was a fight night, where the young women would get the opportunity to have friendly bouts with female British fighters. All proceeds raised would go towards the Afghan team. Additionally, the organizations had arranged for the boxers to meet Jane Couch, MBE, and receive skills and development training. Only one major newspaper, The Guardian (Topping, 2013a; 2013b) reported that the United Kingdom Border Agency (UKBA) turned down visa requests to attend this event. It was reported (Topping, 2013a; 2013b) that their visas were refused on the basis that the boxers could not meet the financial requirements and the risk that they may not return to Afghanistan. Margaret Pope, the director of the Foundation for Women in Sport and coorganizer of the event criticized the UKBA decision as 'bitterly disappointing', and contrary to the 'Olympic legacy' (Topping, 2013b). We believe she is correct, as at the time of the Olympics, AIBA President, Wu Chingkuo had promised to help Afghans, and other developing countries, so they could gain skills and experience in order to compete with more developed countries (Al Jazeera, 2012).

The Western media, in our sample, showcased the talent and problems that rest behind the Afghan female boxing team in the lead up to the 2012 Olympics. The focus was on a few girls and women who have broken through the odds to accomplish extraordinary athletic achievements. Coverage stopped soon after London 2012. This selective coverage distorts the structural inequalities and insecurity that are an ever-present reality for most Afghan girls and women. As Graham-Harrison (2014) highlights, it remains that Afghanistan is one of the worst places for women to live in, let alone box in.

\section{Conclusions}

The boxers of Kabul received significant media attention in the UK/USA during the run-up to the 2012 London Olympics. Not all coverage was accurate, but their stories of boxing appeared in the UK and USA quality press/broadsheets, the dailies/tabloids, and on television news channels. The coverage was selective and the language used was associated, strongly, with the political ideologies of the West's war-on-terror agenda. In other words, the dominant coverage chimed of women's rights, liberation and gender equality, thus reflecting a form of gender Orientalism (Khalid, 2011). 
As Burdsey (2007) has argued, such representations demonstrate the position of sportspeople within political and popular debates over ethnicity, especially Muslim sportswomen and men. Like Amir Kahn, the British male Muslim boxer in Burdsey's analysis, the boxers of Kabul featured in public rhetoric because they are good at what they do - box. However, we cannot forget that the attention and concomitant representations serve and reinforce dominant politics of the time. In the case of Amir Kahn, Burdsey (2007) provides a convincing account of how this young boxer and his ethnicity were framed by the British media to help promote notions of multiethnic Britain under New Labour. There are parallels with how the UK/USA media-and-politics nexus drew upon the boxers of Kabul.

In this chapter we provide some insights into young women's lives as a way to illuminate their experiences of boxing. Clearly, Muslim women are not a homogenous group and the boxers of Kabul experience boxing and Islam in a particular way. The histories and contemporary realities of Afghanistan are important. Their experiences might have some similarities with other Islamic boxers (such as Amir Kahn and the young women in Mintra's (2009) study), but mostly they will not, because of the context of the on-going WOT.

Our main point is that we must remain cautious of organisations, corporations (including media), governing bodies and governments who pay lip service only to the rights of women and girls. Sport participation reflects significant gains for women globally. And yet, participation must be safe and sustainable. This has not been the case for the boxers of Kabul. Without repeating some of the disingenuous media discourse and rhetoric, it is important to acknowledge the passion and physicality of the young women boxers in Afghanistan. As we have discussed, they face daily challenges at many levels in their quest to box.

\section{Bibliography}

Abu-Lughod, L. (2002) Do Muslim Women Really Need Saving? Anthropological Reflections on Cultural Relativism and Its Others. American Anthropologist, 104(3): 783-790.

Ackerman, S. (2013) US Drone Strikes more Deadly to Afghan Civilians than Manned Aircraft. Online: Available from: http://www.theguardian.com/world/2013/jul/02/us-drone-strikesafghan-civilians [Accessed 22 October 2014].

Al Jazeera (2012) 'Afghan Boxer's Dream in Doubt'. Online: Available from: http://www.aljazeera.com/sport/olympics/2012/05/2012522114621912617.html [Accessed 23 July, 2014] 
Amnesty International (2013) 'Women's rights advocates tell of intimidation and attacks'.

Online: Available from: http://www.amnesty.org.au/afghanwomen/comments/31321/

[Accessed 21 July, 2014]

Baker, A. (19 July 2012) The Challenger. Time. Online: Available from:

http://olympics.time.com/2012/07/19/the-challenger-afghanistan-boxer-sadaf-rahimi/

[accessed 16 September, 2014]

Benn, T. and Dagkas, S. (2013) The Olympic Movement and Islamic Culture: Conflict or Compromise for Muslim Women? International Journal of Sport Policy and Politics, 5(2): 281294

Benn, T., Pfister, G. and Jawad, H. (Eds)(2011) Muslim women and Sport, London: Routledge

Boyle, E., Millington, B. and Vertinski, P. (2006) Representing the female pugilist: Narratives of race, gender and disability in Million Dollar Baby, Scociology of Sport Journal, 23( ): 99-116

Burdsey, D. (2007) Role with the punches: the construction and representation of Amir Khan as a role model for multiethnic Britain, The Sociological Review, 55(3): 611-631

Byng, M. (2010) Symbolically Muslim: Media, Hijab, and the West. Critical Sociology. 36(1): 109129.

Caudwell, J. (2008) Girlfight: Boxing Women, Sport in Society, 11(2 \& 3): 227-239

Cortright, D. and Wall, K. (2012) Afghan Women Speak: Enhancing Security and Human Rights in Afghanistan. Kroc Institute for International Peace Studies.

Crane, M. (2009) It Becomes a River: Afghanistan at a Crossroads, World Policy Journal, 26(1): 95-104

Fahmy, S. (2004) Picturing Afghan Women: A Content Analysis of AP Wire Photographs During the Taliban Regime and After the Fall of the Taliban Regime. Gazette. 66(2): 91-112

Falk, R. (2012) Quran Burning: Mistake, Crime and Metaphor. Online: Available from: http://www.aljazeera.com/indepth/opinion/2012 [Accessed 18 July, 2014] 
Fighting for Peace, Cooperation for Peace and Unity. Online: Available from:

http://www.cpau.org.af/our-work/ffp.html [Accessed 21 July, 2014]

Flack, A. and Sadat, H. (2012) 'Afghan Girls Throw Punches, Aim for Olympic Gold,' Online: Available from: http://www.reuters.com/article/2012/01/02/us-afghanistan-boxingidUSTRE80104320120102 [Accessed 18 July, 2014]

Fojas, C., (2009) Sports of spectatorship: Boxing women of colour in Girlfight and beyond, Cinema Journal, 49(1): 103-115

Graham-Harrison, E. (2014) Afghanistan Sill One of the Worst Places to be a Woman, Says EU Ambassador. Online: Available from: http://www.theguardian.com/world/2014 /mar/07/hamid-karzai-afghanistan-women-eu-mellbin [Accessed: 18 July, 2014]

Halbert, C. (1997) TOUGH ENOUGH AND WOMAN ENOUGH: Stereotypes, Discrimination, and Impression Management Among Women Professional Boxers, Journal of Sport and Social Issues, 21(1): 7-36

Hargreaves, J. (2001) Heroines of Sport: The Politics of Difference and Identity. London: Routledge

Hargreaves, J. (1997) Women's Boxing and Related Activities: Introducing Images and Meanings, Body \& Society, 3(4): 33-49

Harkness, G. and Islam, S. (2011) Muslim Female Athletes and the Hijab, Contexts, 10(4): 64-5

Hokim, M. (13 August 2012) Tajikistan: Female Boxer Takes the Country's Only Olympic Medal. Kloop. Available: Online from: http://kloop.info/2012/08/13/tajikistan-female-boxer-takes-thecountry-s-only-olympic-medal [Accessed: 19 September 2014]

Hossaini,M. (2014) Afghan Women Boxers Eye 2016 Olympics. Yahoo News. Online Available from: http://news.yahoo.com/ap-photos-afghan-women-boxers-eye-2016-olympics082548021--spt.html [Accessed: 29 October 2014].

Joseph, T. (2014) Mediating War and Peace: Mass Media and International Conflict. India Quarterly, 70(3): 225-240.

Kay, T. (2006) Daughters of Islam: Family Influences on Muslim Young Women's Participation in 
Sport, International Review for the Sociology of Sport, 41(3-4): 357-373

Khalid, M. (2011) Gender Orientalism and the Representation of the Other in the War on Terror. Global Change, Peace \& Security, 23(1): 15-29

Lindnera, K. (2012) Women's Boxing at the 2012 Olympics: Gender trouble?, Feminist Media Studies, 12 (3): 464-467

Malcom, D., Bairner, A. and Curry, G. (2010) "Woolmergate": Cricket and the Representation of Islam and Muslims in the British Press, Journal of Sport and Social Issues, 34(2): 215-235.

Mennesson, C (2000) 'Hard' Women and 'Soft' Women: The Social Construction of Identities among Female Boxers, International Review for the Sociology of Sport, 35 (1): 21-33

Mintra, P. (2009) Challenging Stereotypes: The Case of Muslim Female Boxers in Bengal, The International Journal of the History of Sport, 26(12): 1840-1851.

Nakamura, Y. (2002) Beyond the Hijab: Female Muslims and Physical Activity, Women in Sport and Physical Activity Journal, 11(2): 21-48

Qadiry, T. (2012) The Afghan girls who live as boys. Online: Available form:

http://www.bbc.co.uk/news/magazine-15262680 [Accessed 17 September, 2014]

Revolutionary Association of the Women of Afghanistan. Online: Available from:

http://www.rawa.org/index.php [Accessed: 17 September, 2014]

Radzi, W.M. (2006) Muslim Women and Sports in the Malay World. Silk Worm Books: Chaing Mai

Rostami-Povey, E. (2007) Afghan Women: Identity and Invasion. Zed Books: London.

Said,E.W. (1978) Orientalism. Penguin Group: London.

Said, E.W. (1981) Covering Islam: How the Media and the Experts Determine How we see the Rest of the World. Routledge \& Kegan Paul PLC: London.

Saeed, A. (2007) Media, Racism and Islamophobia: The Representation of Islam and Muslims in the Media, Sociological Compass 1(2): 443-462. 
Sfeir, L. (1985) The Status of Muslim Women in Sport: Conflict Between Cultural Tradition and Modernization, International Review for the Sociology of Sport, 20(4): 283-306.

Sodiqov, A. (2012) Tajikistan: Female Boxer Fights Odds, Wins Olympic Bronze. Global Voices. Online: Available from: http://globalvoicesonline.org/2012/08/09/female-boxer-delightstajikistan-with-olympic-bronze/ [Accessed: 19 September 2014].

Stabile, C. and Kumar, D. (2005) Unveiling Imperialism: Media, Gender and The War on Afghanistan. Media, Culture and Society, 27(5): 765-782.

Steele, J. (2012) A decade of western folly has erased hope from Afghanistan. Online: Available from: http://www.theguardian.com/commentisfree/2012/dec/10/ten-years-of-western-follyafghanistan [Accessed: 17 September, 2014]

The Boxing Girls of Kabul (2012) Documentary. Directed by Ariel Nasr. [DVD] US: In Demand

Topping, A. (2013a) 'Afghan Female Boxers 'UK Visa Refusal is 'At Odds With Olympic Legacy.' Online: Available from: http://www.theguardian.com/world/2013/mar/08/ afghan-femaleboxers-visa-refusal-row [Accessed: 18 July, 2014]

Topping, A. (2013b) Female Afghan Boxers Lose UK Visa Fight. Online: Available from: http://www.theguardian.com/world/2013/mar/08/afghan-female-boxers-visa-refusal-row [Accessed: 18 July, 2014]

Van Ingen, C. (2013) "Seeing What Frames Our Seeing": Seeking Histories on Early Black Female Boxers, Journal of Sport History, 40 (1): 93-110

Van Ingen, C. \& Kovacsa, N (2012) Subverting the Skirt: Female boxers' "troubling" uniforms, Feminist Media Studies, 12 (3): 460-463

Walseth, and Fasting, K. (2003) Islam's View on Physical Activity and Sport Egyptian Women Interpreting Islam, International Review for the Sociology of Sport, 38(1): 45 60

Wash and Mobasherat, (2012) Afghanistan's First Female Olympic Boxer Eyes London Dream, Online: Available from: http://edition.cnn.com/2012/04/03/world/asia/afghan-female- 
boxer/index.html?iref=allsearch [Accessed: 18 July, 2014]

Wijnen, E. (2012). The Boxing Girls of Kabul. Unpublished MA Thesis, Utrecht University, Netherlands

Women's Hour (2014) Islamophobia and the Veil, Online: Available from: http://

http://www.bbc.co.uk [Accessed: 14 July, 2014]

Zempi, I. and Chakraborti, N. (2014) Islamophobia, Victimisation and the Veil, Basingstoke:

Palgrave Macmillan.

i See http://www.cpau.org.af/our-work/ffp.html for more details

ii See Revolutionary Association of the Women of Afghanistan: http://www.rawa.org

iii According to http://www.worldbank.org 